\title{
COOPERATION FOR TECHNOLOGICAL DEVELOPMENT: AN ANALYSIS IN THE CONTEXT OF FEDERAL UNIVERSITIES OF MINAS GERAIS STATE
}

\section{Humberto Rodrigues Marques}

Mestrando em Administração pela Universidade Federal de Lavras - UFLA hbetorm@hotmail.com (Brasil)

\section{Marcelo de Oliveira Garcia}

Doutorando em Administração da Universidade Federal de Lavras - UFLA og.marcelo@gmail.com (Brasil)

\section{Déborah Lima Scalioni}

Graduanda em Sistemas de Informação pela Universidade Federal de Lavras - UFLA deborahscalioni@hotmail.com (Brasil)

\section{Paulo Henrique de Souza Bermejo}

Doutor em Engenharia e Gestão do Conhecimento pela Universidade Federal de Santa Catarina UFSC

Professor da Universidade Federal de Lavras - UFLA

bermejo@dcc.ufla.br (Brasil)

\begin{abstract}
The open innovation concept emerges as a substantial factor to innovation management of organizations. Given the importance of universities to the innovation system, they also have adapted to this new paradigm. The objective was to identify the main partners of federal universities of Minas Gerais state - Brazil about the technological development. Characterized as qualitative and descriptive, the research was based on secondary data collected in the INPI patent database through the CNPJ of the 11 federal universities. Thus, was evidenced that the interactions carried out by federal universities analyzed are an important way of corroborating for technological development.
\end{abstract}

Keywords: Open Innovation; Cooperation; Universities. 


\section{INTRODUCTION}

The definition of open innovation is different from the concept of closed innovation, mainly with respect to the way in which companies capture ideas for the development of organizational innovations. The open innovation concept, originally defined by Chesbrough (2003), is a recent topic and still not well defined which according to its creator represents the use of internal and external ideas in innovation processes by companies.

In this sense, among several external agents to enable companies to strengthen partnerships for the development of innovation, the universities stand out as an essential actor in the relation with many industries (Venturini, Verbano \& Bron, 2013; Oliveira \& Alves, 2014; Chesbrough \& Vanhaverbeke, 2011). Thereby, in addition to transmitting knowledge through teaching, universities gain a more enterprising character through the production and dissemination of new technologies as point theme researchers (Fujino, Stal \& Plonski, 1999; Marques, Garcia, Pereira \& Gava, 2014; Kalar \& Antoncic, 2015).

Although researches on open innovation have gained a lot of attention in academic researchers in recent years, there are still some unexplored areas that should have more prominence in future research. The studies in open innovation in higher education institutions are still incipient, since most of the researches focuses on information technology industries. Thus, some authors emphasize the need to approach the open innovation theme in universities, as well as the interactions of these with others transmitters of knowledge agents (Janeiro, Proença \& Gonçalves, 2013; Segarra-Blasco \& Arauzo-Carod, 2008; Chesbrough \& Bogers, 2014; Villasalero, 2014).

Understanding the cooperative interaction of universities to the promotion of innovation is important, since it is through these relationships that, mostly through a network, favor those universities and other entities are able to interact to the technological development (Hurtado, Correa \& Cardona, 2013; Janeiro et al., 2013). However, there are few studies exploring the important relationship between open innovation and the entities of a national system of innovation such as universities, since the literature on open innovation has largely focused on firm-centered analyses. (Wang, Vanhaverbeke \& Roijakkers, 2012).

Therefore, there is the need to develop new researches in which universities are analyzed as unities of analysis, since in most studies about the subject, higher education institutions are addressed only as external sources of knowledge, but little explored as main actors in this process. Considering

Revista de Administração e Inovação, São Paulo, v. 13, n.1, p.127-146, jan./mar. 2016. 
the above, we ask in this study: what are the main actors that federal universities of Minas Gerais state interact to technological development, as a way of obtaining knowledge exchange for the promotion of innovation and consecutively patenting?

The goal is to analyze the cooperation of the federal universities of Minas Gerais state on the technological development, seeking to identify the main actors that these universities relates, in the external search of knowledge for technologies development and protection. This research is necessary, as in the Brazilian context universities are highlighted in the promotion and propagation of new technologies on businesses. This is because Brazilian companies are in vast majority of micro and small size, which prevents the production and dissemination of new technologies by them, because they lack the necessary infrastructure for such activity. Thus, analyzing the dynamics of open innovation in higher education institutions is essential to understand and strengthen the actions of the Brazilian public universities, supporting the development of the country.

Still, it is found that Brazil is ranked 15th in the amount of world scientific production (PPG, 2012), being the universities responsible for this acknowledgement, so that, as the Higher Education Institutions (HEIs) have potential in the production of global basic research and, from this, the applied research can be boosted, and universities stand out in the Brazilian technological production. As demonstrated by Thomson Reuters (2013), among the top ten patent holders in Brazil in the years 2013 and 2012, five are public universities, and besides that $27 \%$ of all patents registered in the country belong to these types of organizations.

Public universities of Minas Gerais state are the units of analysis of this study since the state has been institutionalized in the country's innovation process. Among the efforts, is verified the creation of the Intellectual Property Network (IPN) of Minas Gerais state, which constitutes of a nonprofit organization with the mission to spread and implement the policy of Intellectual, Transfer and Innovation Property in the State, having as one of its objectives the promotion of cooperation of its members with other institutions of the country and abroad. The state also has the Foundation of Research Support of the Minas Gerais State - FAPEMIG - agency of induction and fostering to research and scientific and technological innovation of the State, which among the way it operates tries to promote integration between agents of innovation of the state. In addition, the state has the Federal University of Minas Gerais (UFMG), the Federal University of Viçosa (UFV) and FAPEMIG among the major patent depositors in Brazil (Mendes, Gullo \& Guerrante, 2011).

Revista de Administração e Inovação, São Paulo, v. 13, n.1, p.127-146, jan./mar. 2016. 
Therefore, in addition to this introduction, this paper is structured in other six sections. The next section presents the theoretical aspects of open innovation and the context of universities across the innovation processes. Moreover, in the following section are presented the methodological procedures used to meet the objectives of the study. In the fourth and fifth section are presented, respectively, the results and the discussion, involving the cooperation performed by universities in the generation of patents. Finally, in the last two sections are presented the final remarks and the references used to develop the study.

\section{THEORETICAL FRAMEWORK}

The theoretical basis used for the development of this study is presented below. Initially lectures about open innovation, a new paradigm for the management of innovation in today's organizations. Then, it talks about universities across the innovation process, presenting their features and processes to innovate from their academic researches.

\subsection{Open Innovation}

Open innovation considers external knowledge and technologies to the organization as part of the innovation process, i.e., the boundaries of knowledge between organizations and the external environment become permeable (Ghisetti, Marzucchi \& Montresor, 2015). In this sense, the open innovation paradigm usually meets the traditional model of closed innovation, focused on vertical integration in which the research and development activities are developed and disseminated by organizations without cooperation with third parties (West \& Gallagher, 2006).

The open innovation model was presented in the book "Open Innovation: The New Imperative for Creating and Profiting from Technology" by Henry Chesbrough, which was published in 2003, where, according to the author, the idea of opening is that an organization can not innovate in isolation since it depends on many partners to acquire ideas and features. Thus, Chesbrough (2003, p. 43) states "Open Innovation means that valuable ideas can come from inside or outside the company and can go to market form inside or outside the company as well".

Henry Chesbrough studies contributed to the deepening of the thematic by approaching a variety of topics, ranging from the direction of knowledge flows (inward or outward), to the forms of

Revista de Administração e Inovação, São Paulo, v. 13, n.1, p.127-146, jan./mar. 2016. 
openness (alliances, joint ventures, networks, etc.), the parties involved (suppliers, users, competitors, communities), or the impact of openness on innovation performance (Gambardella \& Panico, 2014).

According to Wang et al. (2012), open innovation practices are positively affected by different elements, as a continuous supply of outside knowledge; highly-educated personnel; financial resources; effective legal systems; institutions protecting intellectual property rights. In this sense, Almirall, Lee and Majchrzak (2014) emphasize that open innovation is likely to succeed only when the needs of the entire ecosystem of sources and supporters are organized in ways that foster both competition and collaboration.

The work of Ghisetti et al. (2015) highlights that the way an organization seeks the external knowledge to innovate represents the first pillar in the open innovation mode. In this direction, Huggins, Izushi, Clifton, Jenkins, Prokop, Whitfield (2010) state that the proximity to key knowledge sources is regarded as a key reason for the greater competitiveness of some of the most successful cities and regions in the world. For these authors, the development of advanced regional economies resulted in the use of open innovation, i.e., the knowledge is passed through a regional business culture highly rich in networking or collaborative communities.

In this environment of cooperation and networking for the creation and dissemination of new technologies, Lin (2015) emphasizes that the knowledge generated by universities become an important source of external knowledge for companies that wants to innovate more efficiently, since the universities have less interest in keeping the restricted knowledge for themselves. In this same perspective, Hurtado et al. (2013) emphasize that the business productivity improvement can occur through contributions of the results obtained through universities' research and development, a fact that contributes to the reduction of production costs and consecutively selling prices, corroborating in improvements for customers and producers.

Thereby, as Hurtado et al. (2013) address, the universities, especially the public character ones, have a fundamental role in the search for social transformation in the knowledge generation through the teaching processes, research and social interaction development, increasingly performed in a network system. Thus, in this same perspective Janeiro et al. (2013) emphasize that such networks represent new means of adapting to competitive contexts, avoiding high fixed costs, offsetting risks, and expanding the scope of innovative success.

Revista de Administração e Inovação, São Paulo, v. 13, n.1, p.127-146, jan./mar. 2016. 


\subsection{Universities and the innovation context}

Universities structures have been changing over time, being considered today as important agents in promoting innovation in a society increasingly based on knowledge, as emphasized Fujino et al. (1999), which besides of generating scientific knowledge and qualify labor for the society, the universities are stimulated to promote economic development. In this context, although academic research is perhaps the main activity of the professoriate on ways to expand the frontiers of knowledge, more recently academic scientists have been encouraged to produce applied knowledge, especially in terms of patents (Cowan \& Zinovyeva, 2013).

As demonstrate by Garnica, Oliveira and Torkomian (2006), at the stage where HEIs are, they need to adapt their academic structures in order to act more efficiently in the technology management, as well as make better use the results of their academic researches. This new universities' perspective has gradually changed with the emergence of disciplines like biotechnology, and increased globalization (Rasmussen; Moen; Gulbrandsen, 2006). In this approach, according to Etzkowitz and Leydesdorff (2000), university can play an enhanced role in innovation in increasingly knowledgebased societies.

That way, although the universities and other higher education institutions are an important source of new scientific knowledge (Löfsten \& Lindelöf, 2005) in addition to teaching and research, universities are increasingly expected to take on technology transfer and commercialization as a part of their mission. This development gives new challenges to the institutions in making initiatives to promote commercialization of university knowledge (Rasmussen et al., 2006).

As explain Sampat (2006) and Torres, Ibarra and Arenas (2015), the universities began to contribute to a large amount of industries about the industrial progress, and the universities' knowledge outputs can occur for a diverse number of channels, such as hiring students and faculty of these universities by industries, consulting relationships between university faculty and firms, publications, presentations at conferences, informal communications with industrial researchers, formation of firms by faculty members and licensure of patents by universities, being this last one of many channels through which university research contributes to technical change in industry and economic growth.

However, universities differ from private firms in the ways in which they can appropriate private economic returns from the invention of new technology, since the universities, in order to take

Revista de Administração e Inovação, São Paulo, v. 13, n.1, p.127-146, jan./mar. 2016. 
advantage of the technological development inherent returns, need almost exclusively of technological licensing processes (Shane, 2004). For this, the universities should be aware of ways to protect their inventions, mainly through patenting, so that they can license and get the financial returns of their technological production and contribute to economic growth (Shane, 2004; Cowan \& Zinovyeva, 2013; Wu, Welch \& Huang, 2015). The patenting has generated important questions on academic knowledge generation and dissemination (Zeebroeck, Potterie \& Guellec, 2008).

\section{METHODOLOGY}

The research was characterized as of qualitative nature, which contributed to a better way to further analyze the data, with more complete and detailed assessments of the analyzed data. According to Vieira and Zouain (2009, p. 15), "the qualitative version ensures the richness of the data, allows to see a phenomenon in its totality, as well as facilitates the exploitation of contradictions and paradoxes." These authors emphasize that qualitative research has another important characteristic, since it generally provides rich and well-founded details, as well as explanations about processes in identifiable locations contexts.

The research in relation to objectives can be classified as descriptive, since its main commitment is to describe the interactions with others institutions of the universities of Minas Gerais state about the technological development, intending to finding out what are the main innovation authors who these institutions relate as a way to seek for external knowledge to generate internal research. For this, Cervo and Bervian (2002, p. 67) explain that the descriptive nature research "it is the study and description of the characteristics, existing property or relationships in the community, group or researched reality".

For such purpose, the literature review was carried out through scientific repositories, such as Science Direct, Google Scholar, Web of Science and JSTOR. Through these articles' base searches were performed using terms like "open innovation", "university" and "cooperation", being used alone or in combination with each other. Through this process, it was possible to identify several studies that addressed the open innovation process in organizations, as well as the universities' interactions in promoting innovation. This phase was conducted between April and May, and contributed to the theoretical and analytical foundation of this study.

Revista de Administração e Inovação, São Paulo, v. 13, n.1, p.127-146, jan./mar. 2016. 
As for the information's knowledge, it turns out that it is totally based on secondary data collection. To achieve the goals were analyzed the co-holders of patent applications of all federal universities of Minas Gerais state, in order to verify the cooperation carried out by universities in technological development. Patent applications were obtained through the database of the National Industrial of Industrial Property (INPI). The INPI, created in 1970, is linked to the Ministry of Development, Industry and Foreign Trade (MDIC) of the Brazilian Government, and consists of a federal autarchy responsible for the improvement, dissemination, and management of the Brazilian system of permission and guarantee of industry intellectual property rights (INPI, 2012).

Therefore, as a way to collect the data needs for the research analysis, i.e., patent applications of federal universities of Minas Gerais state, it was used as search criteria the CNPJ of each educational institution. The CNPJ was acquired through the e-MEC, a portal created for electronic processing of several regulation processes of the Brazilian higher education institutions, such as accreditation, re-accreditation, recognition, among others.

We investigated public and federal universities of the Minas Gerais state: Federal University of Alfenas (UNIFAL); Federal University of Itajubá (UNIFEI); Federal University of Juiz de Fora (UFJF); Federal University of Lavras (UFLA); Federal University of Minas Gerais (UFMG); Federal University of de Ouro Preto (UFOP); Federal University of São João del-Rei (UFSJ); Federal University of Triângulo Mineiro (UFTM); Federal University of Uberlândia (UFU); Federal University of Viçosa (UFV); and Federal University of Vales do Jequitinhonha and Mucuri (UFVJM).

\section{RESULTS}

According to the data collected through the search strategy in the INPI patent database, was recovered a total of 1056 patent document deposited, in which 3 refers to UNIFAL, 22 to UNIFEI, 74 to UFJF, 47 to UFLA, 599 to UFMG, 81 UFOP, 13 to UFSJ, 1 to UFTM, 88 to UFU, 124 to UFV, and 4 to UFVJM. Thus, we could see that the institutions more institutionalized as the production and patent protection are, respectively, UFMG, UFV, UFU and UFOP.

Regarding the patent distribution that have partnership in its developments, we could see that approximately $22 \%$ of 1056 analyzed documents were developed in partnership with other institutions. It is noted that this analysis did not consider as partnerships for the patent development the 
development agencies, like FAPEMIG and FAPESP, since the goal of these institutions is the funding transfer, and not external knowledge to generate new research, the object of analysis in this study.

Figure 1 shows the patents split of each university institution between the patents that have been developed in partnership with other institutions and patents without partnership with third parties for its development. Thus, it is found that UFVJM, UFSJ and UNIFAL had the higher percentage of their patents deposits developed in cooperation with other organizations, while UFTM, UFLA and UFV were the universities that had less percentage possessed, among its total deposits, of patents with co-holders.

Figure 1 - Patents developed with and without partnerships by analyzed universities

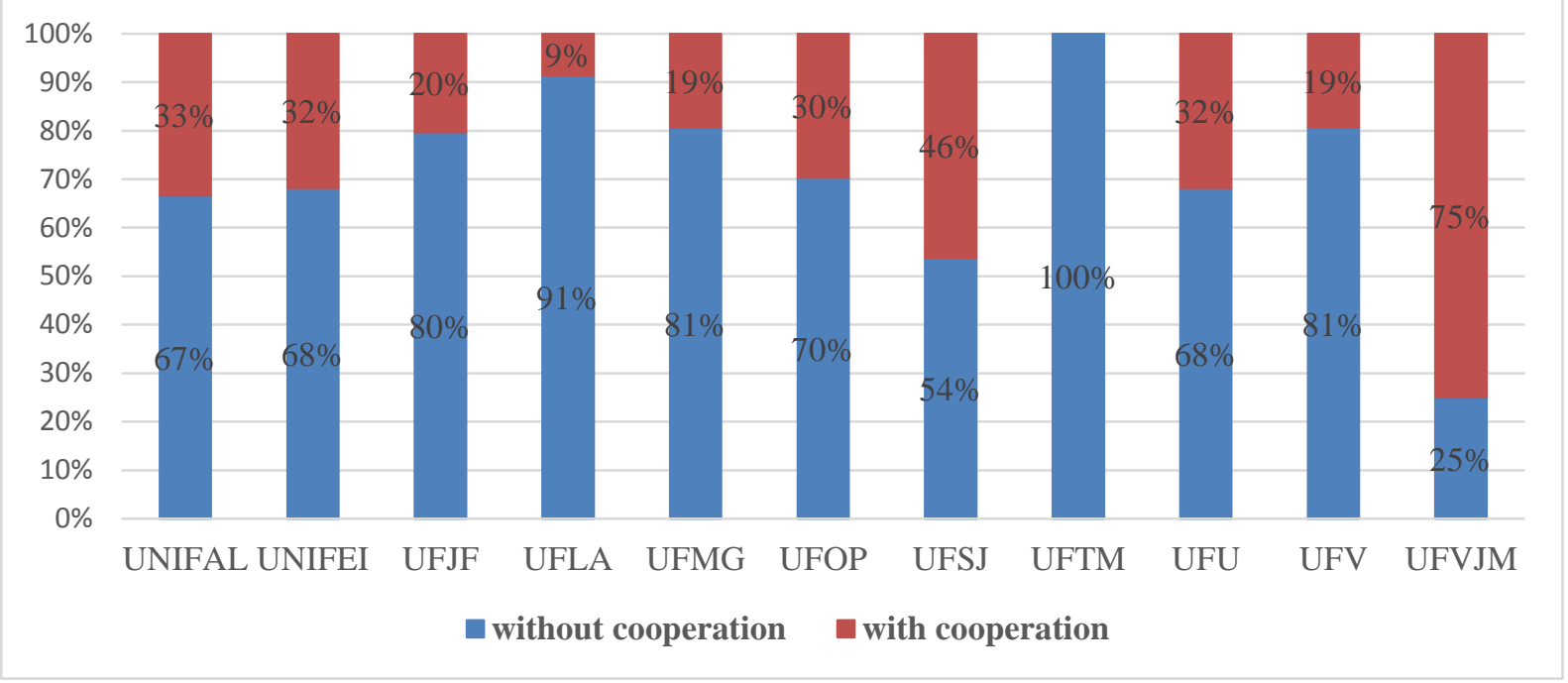

Source: Elaborated by the authors (2015)

Therefore, among 228 patents that have partnerships with other institutions for its development and protection, we find that these documents belong to 112 different partners, and they include individuals, public institutions such as autarchies, foundations and companies, and private organizations, such as companies and educational institutions. Thus, when analyzing these partners of 228 patents with co-holders, it turns out that 55\% refers to partnerships with public institutions, $35 \%$ with private institutions and $10 \%$ with individuals.

When analyzing the distribution of these partner institutions by the analyzed universities, as shown in Figure 2, it can be seen that from 11 educational institutions studied, 9 universities had the public institutions as the major partner in the development of new patents, and only UNIFEI, which 
has 4 deposits with co-holders, had private organizations as the major partners. Moreover, UFTM with only one deposit does not have patents developed with other institutions.

Figure 2 - Partners in the development of patents by each institution

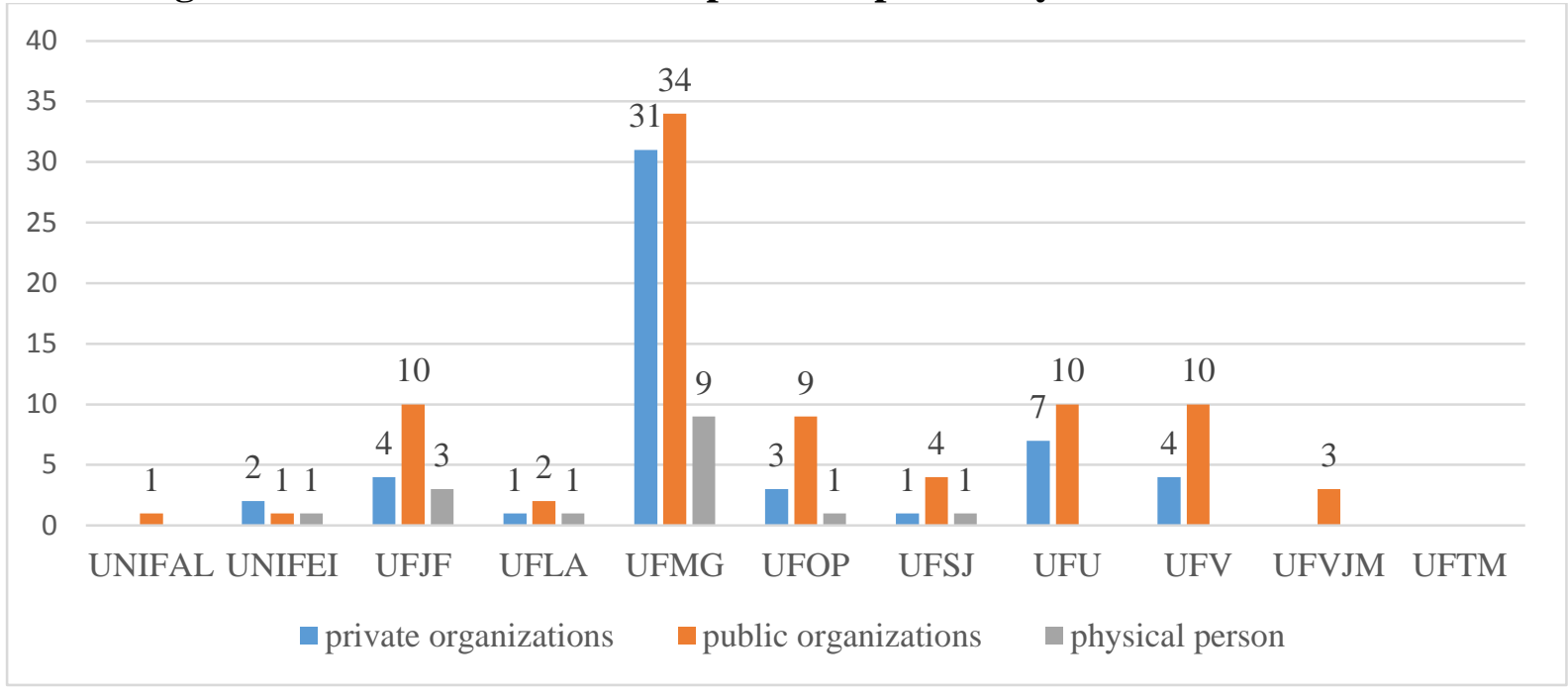

Source: Elaborated by the authors (2015)

With respect to the 17 institutions that collaborated most with the universities for the development of new patents, it can be seen according to Figure 3 that $71 \%$ of these are of public nature. Is also noted that these highlighted public institutions represent $43 \%$ of all partnerships established in the analyzed patents. This emphasizes the role played by educational institutions, since from 17 institutions highlighted, 7 are educational institutions, being UFMG, UFOP, UFV and USP the largest participants. It is emphasized that from the 5 private companies that have collaborated more with the IES analyzed, two were originated from the partnership with the teaching institutions themselves, the ECOVEC S.A., an academic spin-off originated from researches in the UFMG, and Intec Consulting and Advisory Ltda, company linked to the Incubator of Technology-Based Companies of UFV. 
Figure 3 - Main partners in the development of new patents

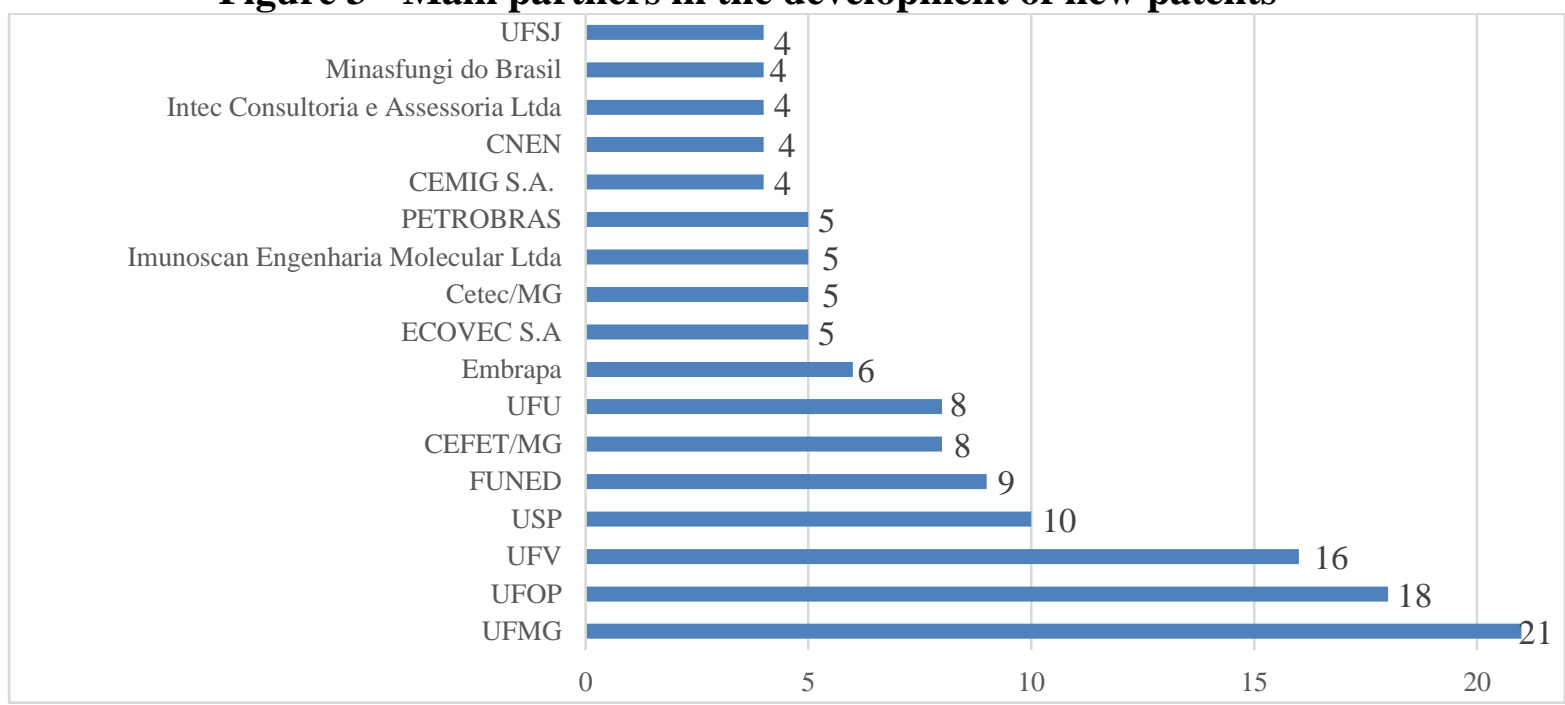

Source: Elaborated by the authors (2015).

Among the partners institutions it can also be highlighted the link of the universities of Minas Gerais state analyzed with foreign organizations. This partnerships have occurred by the UFLA with Joseph Colasanti, a professor in the Department of Cell and Molecular Biology at the University of Guelph, in Canada, and by the UFMG, who owned 8 international partnerships, being with 4 educational institutions, the Duke University and Northeastern University, both private universities in the USA, the Syddansk Universitet, a public educational institution in Denmark, and the University of Southampton, a public university in England. Moreover, the UFMG has patterned with the Centre National de la Recherche Scientifique, the largest public agency for scientific research in France, with Eisai R\&D Management CO., LTD, a company based in Japan, with the Ludwig Institute for Cancer Research Lt, an international community of distinguished scientists dedicated to the prevention and control of cancer based in the US, and finally, with Yasser Ragab Shaban, linked to the University of Illinois in the United States.

When analyzing the evolution of the patents deposits with partnership and without partnership, we find that deposits in partnership with other institutions, although are still lower than deposits without partnership, they follow the growing rate of deposits without partnership, having a growth rate since 2000s, having a peak in 2012, and later showed a decline. Until the time of collection, May 2015, all three deposits made in this year were through partnerships.

Revista de Administração e Inovação, São Paulo, v. 13, n.1, p.127-146, jan./mar. 2016. 


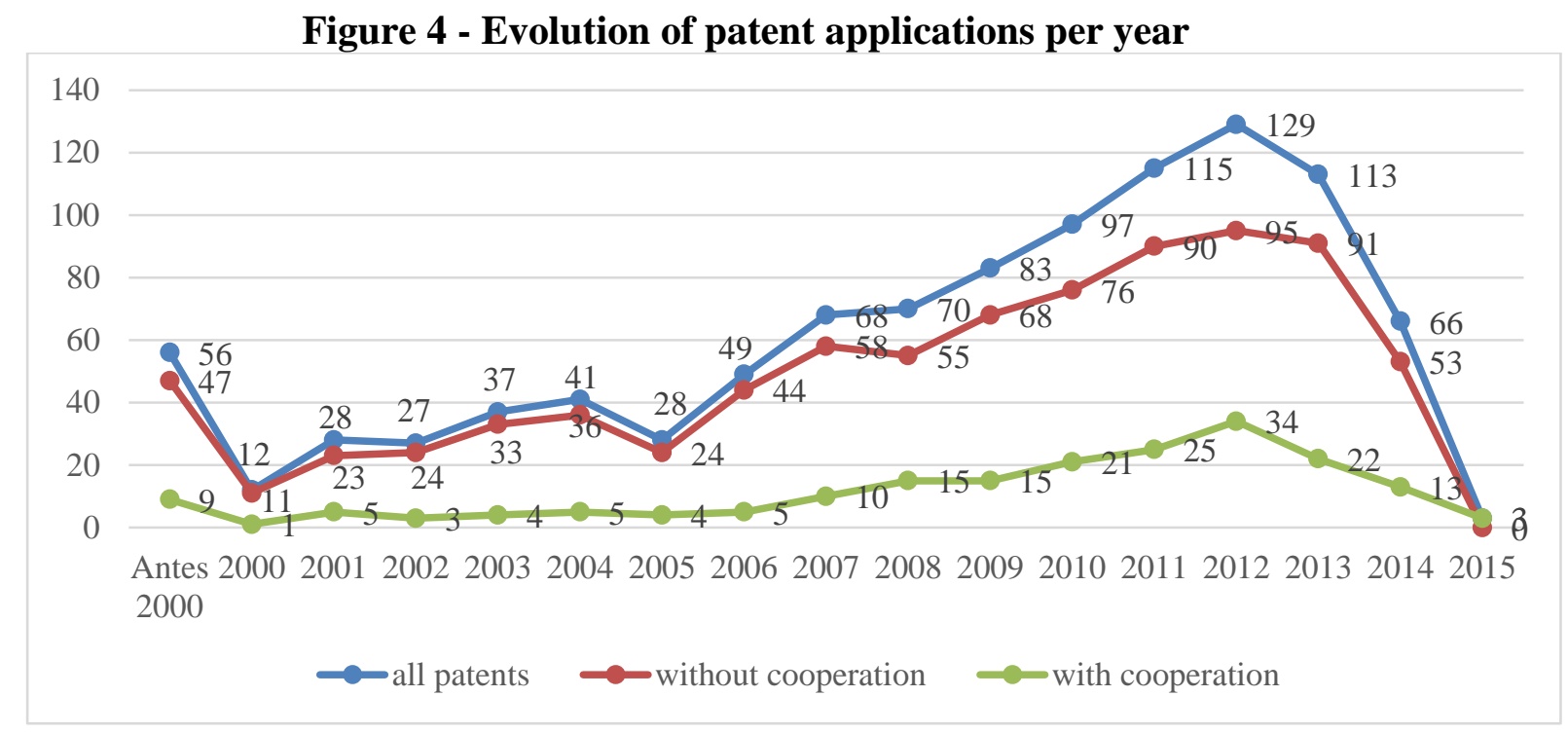

Source: Elaborated by the authors (2015)

Finally, we analyze the international patent classification (IPC), a classification established by the Strasbourg Agreement in 1971, which foresee a hierarchical system of independent symbols for the classification of patents and utility models, according to the different technology areas to which they belong. The IPC divides technology into eight sections, with approximately 70,000 subdivisions. Each subdivision has a symbol consisting of Arabic numerals and Latin letters of the alphabet. As we can see in Table 1, the recovered patents have IPCs in all 8 sections. It is emphasized that a patent application can be rated with more than one IPC.

Table 1 - Distribution of patents' international patent classification with partnership

\begin{tabular}{|c|c|c|}
\hline $\mathrm{n}^{\circ}$ requested & & IPC \\
\hline 57 & A & Human Needs \\
\hline 8 & A01 & Agriculture; Forestry; Animal Husbandry; Hunting; Trapping; Fishing \\
\hline 2 & $\mathrm{~A} 23$ & Foods or Foodstuffs; their treatment, not covered by other classes \\
\hline 1 & A43 & Footwear \\
\hline 45 & A61 & Medical or Veterinary Science; Hygiene \\
\hline 1 & A63 & Sports; Games; Amusements \\
\hline 23 & B & Performing Operations; Transporting \\
\hline 9 & B01 & Physical or Chemical Processes or Apparatus in General \\
\hline 2 & B03 & $\begin{array}{c}\text { Separation of Solid Materials Using Liquids or Using Pneumatic Tables or Jigs; Magnetic or } \\
\text { Electrostatic Separation of Solid Materials From Solid Materials or Fluids; Separation by High- } \\
\text { Voltage Electric Fields }\end{array}$ \\
\hline 1 & B23 & Machine Tools; Metal-Working Not Otherwise Provided for \\
\hline 1 & B29 & Working of Plastics; Working of Substances in a Plastic State, in General \\
\hline 1 & B32 & Layered Products \\
\hline 1 & B63 & Ships Or Other Waterborne Vessels; Related Equipment \\
\hline
\end{tabular}

Revista de Administração e Inovação, São Paulo, v. 13, n.1, p.127-146, jan./mar. 2016. 


\begin{tabular}{|c|c|c|}
\hline 2 & B65 & Conveying; Packing; Storing; Handling Thin Or Filamentary Material \\
\hline 6 & B82 & Nano-Technology \\
\hline 65 & $\mathrm{C}$ & Chemistry; Metallurgy \\
\hline 4 & $\mathrm{C} 01$ & Inorganic Chemistry \\
\hline 9 & $\overline{\mathrm{C} 02}$ & Treatment Of Water, Waste Water, Sewage, Or Sludge . \\
\hline 4 & $\overline{\mathrm{C} 04}$ & Cements; Concrete; Artificial Stone; Ceramics; Refractories \\
\hline 1 & $\overline{\mathrm{C} 05}$ & Fertilisers; Manufacture Thereof \\
\hline 15 & $\mathrm{C} 07$ & Organic Chemistry \\
\hline 11 & C08 & $\begin{array}{c}\text { Organic Macromolecular Compounds; Their Preparation Or Chemical Working-Up; Compositions } \\
\text { Based Thereon }\end{array}$ \\
\hline 3 & $\mathrm{C} 09$ & $\begin{array}{c}\text { Dyes; Paints; Polishes; Natural Resins; Adhesives; Miscellaneous Compositions; Miscellaneous } \\
\text { Applications Of Materials }\end{array}$ \\
\hline 2 & C10 & $\begin{array}{l}\text { Petroleum, Gas Or Coke Industries; Technical Gases Containing Carbon Monoxide; Fuels; } \\
\text { Lubricants; Peat }\end{array}$ \\
\hline 12 & $\mathrm{C} 12$ & $\begin{array}{c}\text { Biochemistry; Beer; Spirits; Wine; Vinegar; Microbiology; Enzymology; Mutation Or Genetic } \\
\text { Engineering }\end{array}$ \\
\hline 2 & $\mathrm{C} 21$ & Metallurgy Of Iron \\
\hline 2 & $\mathrm{C} 40$ & Combinatorial Chemistry \\
\hline 6 & $\mathrm{E}$ & Fixed Constructions \\
\hline 1 & E01 & Construction Of Roads, Railways, Or Bridges \\
\hline 2 & E03 & Water Supply; Sewerage \\
\hline 2 & E04 & Building \\
\hline 1 & $\bar{E} 21$ & Earth Drilling; Mining \\
\hline 7 & $\mathrm{~F}$ & Mechanical Engineering; Lighting; Heating; Weapons; Blasting Engines Or Pumps \\
\hline 3 & $\overline{\mathrm{F} 02}$ & Combustion Engines; Hot-Gas Or Combustion-Product Engine Plants \\
\hline 2 & F03 & $\begin{array}{l}\text { Machines Or Engines For Liquids; Wind, Spring Weight And Miscellaneous Motors; Producing } \\
\text { Mechanical Power; Or A Reactive Propulsive Thrust, Not Otherwise Provided For }\end{array}$ \\
\hline 2 & F16 & $\begin{array}{l}\text { Engineering Elements And Units; General Measures For Producing And Maintaining Effective } \\
\text { Functioning Of Machines Or Installations; Thermal Insulation In General }\end{array}$ \\
\hline 35 & G & Physics \\
\hline 27 & G01 & Measuring; Testing \\
\hline 2 & G05 & Controlling; Regulating \\
\hline 4 & G06 & Computing; Calculating; Counting \\
\hline 1 & G08 & Signaling \\
\hline 1 & G09 & Education; Cryptography; Display; Advertising; Seals \\
\hline 2 & $\mathrm{H}$ & Electricity \\
\hline 1 & H01 & Basic Electric Elements \\
\hline 1 & H04 & Electric Communication Technique \\
\hline
\end{tabular}

Source: Elaborated by the authors (2015)

According to the verified, the IPC with more classifications is the "C" which refers to chemistry and metallurgy, where the subdivisions that stand out are "C07" related to Organic Chemistry, and "C12" referring to Biochemistry; Beer; Spirits; Wine; Vinegar; Microbiology; Enzymology; Mutation Or Genetic Engineering. The second IPC with higher deposits refers to section "A", which matches the Human Needs, and has the "A61" subdivision, referring to Medical or Veterinary Science; Hygiene, the one that stands out most. 
The next section will present a discussion about the results of this study.

\section{DISCUSSION}

The current socio-economic system has suffered constant changes, a fact that confirms the modification in the way of thinking and acting on society, context in which there is greater attention to several other elements that give organizations the need to look for alternative ways to stay active and competitive in the market (Borges, Lima, Vilela \& Morais, 2004; Morschel, Costa, Reis \& Matos, 2013; Machado, Gomes, Trentin, \& Silva, 2014; Marques et al., 2014). In this new economic model, the innovation has gained a major focus to organizations (EFRAT, 2014). In this matter the universities gain prominence, since they contribute to the generation of new technologies for having knowledge and necessary requirements for such activity (Wu, Chen \& Chen, 2010; Maietta, 2015; Marques et al. 2014).

In Brazil, the universities gain prominence, since as understood, is assumed that the applied research originates from basic research, and educational institutions, according to Löfsten and Lindelöf (2005), are responsible for the scientific knowledge's production and dissemination. Brazil is responsible for $53 \%$ of the scientific production in Latin America and occupies $15 \%$ in the volume of global scientific production (PPG, 2012). Still, given the scientific potential of IES, and that technological production emerges from basic research, they account for $27 \%$ of patent production in the country, and 5 of the 10 largest depositors in the country are public universities, according to Thomson Reuters (2013).

Thereby, it is verified that the state of Minas Gerais has being institutionalized as promoting patents development, since it has an Intellectual Property Network (IPN) of Minas Gerais state, as well as a development agency for this purpose, the FAPEMIG. Thus, analyzing the interactions for patent production in federal universities of Minas Gerais state is necessary to understand the status of the innovation dynamics. As discoursed Cowan and Zinovyeva (2013), the human capital associated with traditional university production, as measured by scientific publications and their citations, has a strong effect on innovation.

As it was observed, there was a growth of patent filings with and without partnerships by federal universities of Minas Gerais state, especially until the year of 2012. This increase demonstrates the influence of the universities in a country's innovation system, because as emphasize Cowan and

Revista de Administração e Inovação, São Paulo, v. 13, n.1, p.127-146, jan./mar. 2016. 
Zinovyeva (2013), the increase of innovation activity during past decades directly influences the size of the university sector.

It was also found that public institutions, especially public universities, were the institutions that cooperated most with the analyzed universities. As emphasize Hurtado et al. (2013), the main contribution of university networks with the purpose of research and development compared to other networks is the satisfaction of a social need.

However, several private companies were observed in interactions with universities. As reported by Chesbrough (2003), the open innovation is a way for companies to collaborate with external sources of innovation, such as competitors, suppliers, customers and universities. Accordingly, according to Janeiro et al. (2013), more cooperation between firms and universities might quickly bring a greater diffusion of knowledge, better results from firm innovation, and training programs for students. Thus, partnerships with universities emerge as a chance to promote to businesses the necessary assistance for the generation of research and development (Segatto-Mendes \& Rocha, 2005).

It can be verified in the analyzed results that universities like UFLA and UFMG owned partnership with foreign institutions from various countries, such as Denmark, United States, Canada and the United Kigndom. As emphasized Hurtado et al. (2013), in economic relations between universities and other organizations and interest groups, there are links with actors from different geographical locations, which are influenced by the network concept. Also according to the authors, the physical limits do not constitute a barrier to the satisfaction of social needs, as through a network where there is direct exchange of information and knowledge in real time, the geographical distance ceases. Still, as addresses Vick (2015), the Brazilian scientists beyond partnerships with national companies, perform partnerships with transnational companies, and have developed original projects that result in innovations with the potential to compete with technologies produced in major world centers.

Regarding the areas where patents were developed, it can be seen that the patents' deposits, despite involving all IPC sections, which shows that there is great heterogeneity in the research developed by universities, there were two groups of patents that stood out, the ones related to chemistry and metallurgy, as well as the ones related to human needs. According to Shane (2004), the patenting imposes a cost that, from an economic perspective, and for this reason the universities are more motivated to develop technologies in sectors where licensing for the market is more effective

Revista de Administração e Inovação, São Paulo, v. 13, n.1, p.127-146, jan./mar. 2016. 
since they are motivated by economic return. Thus, it can be concluded that the patents concentrations in two IPC groups are by the fact that universities are looking for more profitable sectors of technology.

\section{CONCLUSION}

The competition context in which organizations are inserted require them to increasingly direct its activities to innovation processes, if they want to remain active and competitive in the market. Is still essential that organizations seek for external knowledge, since they will hardly be able to innovate by themselves, without cooperation of other organizations of the environment where they are inserted. In this context there are the universities, which like every organization, it should suit the new socioeconomic context and also capture external knowledge for the knowledge generation and dissemination. In this sense, the objective of this study covered to identify what are the main actors that federal universities of Minas Gerais state are relating to generate new technologies.

According to the results, it can be seen that some federal universities of Minas Gerais state are more institutionalized than others as the generation and patent protection, since while institutions such as UFMG and UFV owned large amount of patent applications, other universities as UFVJM and UFTM owned few deposits. Still, it was found that there was an evolution of deposits with co-holders between 2000 and 2012, with a decline later, as observed in the patents without partnership in its development. In addition, we could observe that among the partner institutions of the analyzed universities most are of a public nature, being the public educational institutions the ones that have developed more partnerships such as UFMG, UFOP, UFV and USP. Finally, we can notice that there were some partnerships with foreign institutions from countries like Canada, Denmark, the United States and England, showing a geographical approach in the development of innovation.

The contributions of this study refer to the possibility of demonstrating the importance of the partnership to generate new technologies for universities, since the literature on open innovation the research focuses on companies as units of analysis. Thus, this study supports the mapping of the partners of federal universities of Minas Gerais state, thus contributing to realize the importance of universities to produce innovation in the country.

The limitations and new opportunities for future research, first of all, we used only data from federal universities of Minas Gerais state, so that, despite being the objective to analyze whether these

Revista de Administração e Inovação, São Paulo, v. 13, n.1, p.127-146, jan./mar. 2016. 
institutions were institutionalized as cooperation with other institutions in the development of research, the analysis of other public educational institutions of the country could help to increase the discussion on the subject. Also, it was used only secondary data, so it is possible, through an analysis of primary data with stakeholders in the IFES innovation process, get through primary data more detailed information about the process of cooperation of IFES with external institutions, identifying the process, the limitations and difficulties of such cooperation. Finally, the study did not investigate the patents' quality, which could check if the inventions have been absorbed by businesses and transformed into innovation.

\section{REFERÊNCIAS}

Almirall, E., Lee, M., \& Majchrzak, A. (2014). Open innovation requires integrated competitioncommunity ecosystems: Lessons learned from civic open innovation. Business Horizons, 57(3): 391400 .

Borges, L. O., Lima, A. M. S., Vilela, E. C., \& Morais, S. D. S. G. (2004). Comprometimento no trabalho e sua sustentação na cultura e no contexto organizacional. RAE-eletrônica, 3(1): 1-24.

Chesbrough, H. (2003). Open Innovation: The New Imperative for Creating and Profiting from Technology. Boston: Harvard Business Press.

Chesbrough, H., \& Bogers, M. (2014). Explicating open innovation: clarifying an emerging paradigm for understanding innovation. New Frontiers in Open Innovation. Oxford: Oxford University Press, Forthcoming, 3-28.

Chesbrough, H.; Vanhaverbeke, W. (2011). Open innovation and public policy in Europe. Bruxelas: Science Business Publishing Ltd.

Cowan, R., \& Zinovyeva, N. (2013). University effects on regional innovation. Research Policy, 42 (3): $788-800$.

Efrat, K. (2014). The direct and indirect impact of culture on innovation.Technovation, 34 (1): 12-20.

Etzkowitz, H., \& Leydesdorff, L. (2000). The dynamics of innovation: from National Systems and "Mode 2" to a Triple Helix of university-industry-government relations. Research policy, 29 (2): 109123.

Fujino, A., Stal, E., \& Plonski, G. A. (1999). A proteção do conhecimento na universidade. Revista de Administra\&ccdeil; ão da Universidade de São Paulo, 34 (4).

Revista de Administração e Inovação, São Paulo, v. 13, n.1, p.127-146, jan./mar. 2016. 
Gambardella, A., \& Panico, C. (2014). On the management of open innovation. Research Policy, 43 (5): 903-913.

Garnica, L. A., OLIVEIRA, R. D., \& Torkomian, A. L. V. (2006). Propriedade intelectual e titularidade de patentes universitárias: um estudo piloto na Universidade Federal de São CarlosUFSCar. XXIV Simpósio de Gestão da Inovação Tecnológica, 1-16.

Ghisetti, C., Marzucchi, A., \& Montresor, S. (2015). The open eco-innovation mode. An empirical investigation of eleven European countries. Research Policy, 44 (5): 1080-1093.

Huggins, R., Izushi, H., Clifton, N., Jenkins, S., Prokop, D., \& Whitfield, C. (2010). Sourcing knowledge for innovation: the international dimension.

Hurtado, C. D., Correa, Z. C., \& Cardona, Y. A. C. (2013). The role of a public university in a global environment: networks and externalities of the R\&D of the Cauca University. Estudios Gerenciales, 29 (129): 396-405.

INSTITUTO NACIONAL DE PROPRIEDADE INDUSTRIAL (INPI). (2015). Institucional: O INPI. http://www.inpi.gov.br/sobre/estrutura Accessed 14 June 2015.

Janeiro, P., Proença, I., \& da Conceição Gonçalves, V. (2013). Open innovation: Factors explaining universities as service firm innovation sources. Journal of Business Research, 66 (10): 2017-2023.

Kalar, B., \& Antoncic, B. (2015). The entrepreneurial university, academic activities and technology and knowledge transfer in four European countries. Technovation, 36: 1-11.

Lin, S. (2015). Are ivory towers truly ivory? Knowledge spillovers and firm innovation. Journal of Economics and Business, 80: 21-36.

Löfsten, H., \& Lindelöf, P. (2005). R\&D networks and product innovation patterns-academic and non-academic new technology-based firms on Science Parks. Technovation, 25(9): 1025-1037.

Machado, D. D. P. N., Gomes, G., Trentin, G. N. S., \& Silva, A. (2014). Cultura de inovação: elementos da cultura que facilitam a criação de um ambiente inovador. RAI: revista de administração e inovação, 10 (4): 164-182.

Maietta, O. W. (2015). Determinants of university-firm R\&D collaboration and its impact on innovation: A perspective from a low-tech industry. Research Policy, 44 (7): 1341-1359.

Marques, H. R., de Oliveira Garcia, M., Pereira, R. M., \& Gava, R. (2014). Monitoramento Tecnológico: Estudo de uma Propriedade Intelectual da Universidade Federal de Viçosa. Revista Cereus, 6 (1): 105-24.

Mendes, C. D. De S.; Gullo, L. M. G.; Guerrante, R. D. S. (2011). Principais titulares de pedidos de patentes no Brasil, com prioridade brasileira: depositados no período de 2004 a 2008, Instituto Nacional da Propriedade Industrial, [s. 1.].

Morschel, E. L., Costa, V. L., Reis, D. R., \& Matos, E. A. S. A. (2013). A Influência da Cultura Organizacional no Processo de Inovação: O Caso da Águia Sistemas de Armazenagem em Ponta Grossa, Paraná. Revista de Administração e Inovação-RAI, 10 (2): 219-237. 
Oliveira, S. M., \& Alves, J. L. (2014). Influência das práticas de inovação aberta na prospecção de conhecimentos para a criação de valor em ambientes de alta complexidade sob condições de incerteza e imprevisibilidade. RAI: revista de administração e inovação, 11 (1): 295-318.

Pró-Reitoria de Pesquisa e Pós-Graduação da Universidade Federal de Viçosa (Ppg). (2012). Research and graduate studies. Folder.

Rasmussen, E., Moen, Ø., \& Gulbrandsen, M. (2006). Initiatives to promote commercialization of university knowledge. Technovation, 26 (4): 518-533.

Sampat, B. N. (2006). Patenting and US academic research in the 20th century: The world before and after Bayh-Dole. Research Policy, 35 (6): 772-789.

Segarra-Blasco, A., \& Arauzo-Carod, J. M. (2008). Sources of innovation and industry-university interaction: Evidence from Spanish firms. Research Policy, 37 (8): 1283-1295.

Segatto-Mendes, A. P., \& Rocha, K. C. (2005). Contribuições da teoria de agência ao estudo dos processos de cooperação tecnológica universidade-empresa. Revista de Administração da Universidade de São Paulo,40 (2): 172-183.

Shane, S. (2004). Encouraging university entrepreneurship? The effect of the Bayh-Dole Act on university patenting in the United States. Journal of Business Venturing, 19 (1): 127-151.

Thomson Reuters. (2013). Brasil: atuais desafios e tendências da inovação. 2013.

Torres, L. T. R., Ibarra, E. R. B., \& Arenas, A. P. L. (2015). Open Innovation Practices: A Literature Review of Case Studies. Journal of Advanced Management Science Vol, 3(4).

Venturini, K., Verbano, C., \& Bron, A. (2013). Openness and innovation: an empirical analysis in firms located in the Republic of San Marino.International Journal of Engineering, Science and Technology, 5 (4): 60-70.

Vick, T. E., Nagano, M. S., \& Popadiuk, S. (2015). Information culture and its influences in knowledge creation: Evidence from university teams engaged in collaborative innovation projects. International Journal of Information Management, 35 (3): 292-298.

Villasalero, M. (2014). University knowledge, open innovation and technological capital in Spanish science parks: Research revealing or technology selling?. Journal of Intellectual Capital, 15 (4): 479496.

Wang, Y., Vanhaverbeke, W., \& Roijakkers, N. (2012). Exploring the impact of open innovation on national systems of innovation-A theoretical analysis. Technological Forecasting and Social Change, 79 (3): 419-428.

West, J., \& Gallagher, S. (2006). Patterns of open innovation in open source software. Open Innovation: researching a new paradigm, 235 (11).

Revista de Administração e Inovação, São Paulo, v. 13, n.1, p.127-146, jan./mar. 2016. 
Wu, H. Y., Chen, J. K., \& Chen, I. S. (2010). Innovation capital indicator assessment of Taiwanese Universities: A hybrid fuzzy model application.Expert Systems with Applications, 37 (2): 1635-1642.

Wu, Y., Welch, E. W., \& Huang, W. L. (2015). Commercialization of university inventions: Individual and institutional factors affecting licensing of university patents. Technovation, 36: 12-25.

Zeebroeck, N. V, Potterie, B. V. P., \& Guellec, D. (2008). Patents and academic research: a state of the art. Journal of Intellectual Capital, 9 (2): 246-263.

The date of receipt: 10/17/2015

The date of acceptance: 02/05/2016 